Nat. Hazards Earth Syst. Sci. Discuss., https://doi.org/10.5194/nhess-2018-129

Manuscript under review for journal Nat. Hazards Earth Syst. Sci.

Discussion started: 11 June 2018

(c) Author(s) 2018. CC BY 4.0 License.

\title{
Drought Risk Assessment by Using Drought Hazard and Vulnerability Indexes
}

\author{
Ismail Dabanli ${ }^{\mathrm{a}, \mathrm{b}}$ \\ aIstanbul Medipol University, School of Engineering and Natural Sciences, Civil Engineering Department, 34810, \\ 5 Istanbul, Turkey \\ ${ }^{\mathrm{b}}$ Clemson University, Glenn Department of Civil Engineering, Clemson, 29634, SC, USA
}

\begin{abstract}
Drought has multiple impacts on socioeconomic sectors and it is expected to increase in the coming years due to nonstationary nature of climate variability and change. Here, we investigated drought hazard, vulnerability, and risk based on hydro-meteorological and actual socio-economic data for provinces of Turkey. Although, drought vulnerability and risk assessment are essential parts of drought phenomenon, so far, lack of proper integrated drought risk assessment in Turkey (and elsewhere) has led to higher socio-economic impacts. Firstly, the Drought Hazard Index (DHI) is derived based on the probability occurrences of drought using Standardized Precipitation Index (SPI) to facilitate the understanding of drought phenomenon. Secondly, the Drought Vulnerability Index (DVI) is calculated by utilizing four socio-economic indicators to quantify drought impact on society. Finally, the Drought Risk Index (DRI) is obtained by multiplying DHI and DVI for provinces of Turkey to highlight the relative importance of hazard and vulnerability assessment for drought risk management. A set of drought hazard, vulnerability, and composite risk maps were then developed. The outputs of analysis reveal that among 81 administrative provinces in Turkey, 73 provinces are exposed to the low drought risk $(0<$ DRI < 0.25), 6 provinces to the moderate drought risk $(0.25<\mathrm{DRI}<0.50)$, and 1 province (Konya) to the high drought risk $(0.50<\mathrm{DRI}<0.75)$. These maps can assist stakeholders to identify the regions vulnerable to droughts, thus helping in development of mitigation strategies as well as effective water resources management in a consistently drought prone provinces.
\end{abstract}

Keywords: Drought, SPI, DRI, hazard, risk, vulnerability, Turkey

\section{Introduction}

Drought can be defined as a recurring climate phenomenon over land characterized by water deficit over a period of months to years. Extreme drought conditions are known to predominantly influence agriculture, environment and health translating into severe socio-economic repercussions (Rahman and Lateh, 2016; Mishra and Singh, 2010; Dai, 2013). Global climate model projections indicated an increase in drought occurrence resulting from either decreased precipitation and/or increased evaporation (Dai, 2011; Trenberth, 2011). In addition to that, the global water demand is set to increase due to rapid population growth as well as globalization (Zhang et al., 2011). Being located in a sensitive climate change hotspot, the Mediterranean region is not immune to these global changes (Diffenbaug and Giorgi, 2012). Studies have indicated an increase in frequency (Venkataraman et al., 2016) and severity (Gampe et al., 2016) of Mediterranean droughts. In Turkey, the drought occurrence and severity follows similar to Mediterranean patterns. As a result, several studies have evaluated diverse characteristics of droughts specific to Turkey. Some of the major contributions include : quantifying the intensity, severity and duration of droughts by the utilizing various drought indices (Şen, 2015); modeling drought propagation and occurrences to assist in drought planning and mitigation (Tosunoglu and Can, 2016); establishing teleconnections to major climate oscillations by spatio temporal frequency analysis (Dogan et 
Nat. Hazards Earth Syst. Sci. Discuss., https://doi.org/10.5194/nhess-2018-129

Manuscript under review for journal Nat. Hazards Earth Syst. Sci.

Discussion started: 11 June 2018

(c) Author(s) 2018. CC BY 4.0 License.

Natural Hazards
and Earth System
Sciences

Discussions

al., 2012); paleoclimate reconstruction of drought series (Türkeş and Erlat, 2010) and assessing the impact of climate change on drought characteristics (Şen, 2015). These studies have allowed us to advance our understanding on various drought characteristics in Turkey. However, research related to drought risk assessment in a socio-economic context is still in its nascent stage. The assessment of socio-economic vulnerability to drought is extremely essential to plan the future policy actions to reduce the potential for damage (Rajsekhar et al., 2015). In this direction, Sönmez et al., (2005) have estimated that the drought poses significant risk to agriculture in the region of South-eastern Anatolia from a climatological perspective. Whereas, Kahraman and Kaya, (2009) estimated the drought risk on Istanbul dams using several processes based indices and Şen et al., (2012) estimated the drought risk associated with crop productivity for future projections. However, based on our knowledge, the socio-economic impact (risk) of drought for Turkey has not been investigated. Socio economic aspects usually involve factors like population density, agricultural land, access to domestic water, etc. It is expected that a drought in region with high socio-economic value would result in more loss than the others (Mishra and Singh, 2010). Over the past 30 years, Turkey has experienced a tremendous growth in urbanization fueled by its open economic policies and industrialization (World Bank Report, 2015). These changes make the Turkey more vulnerable to droughts. It is therefore necessary to have a comprehensive understanding of drought implications on socio-economic sectors in terms of hazard, vulnerability and risk assessments.

Globally, many studies have emphasized that a suitable way to assess the drought risk is by combining the socioeconomic hazard and vulnerability of a region (Jia and Wang, 2016; Pei et al., 2016; Shahid and Behrawan, 2008; Verdon-Kidd and Kiem, 2010; Lin et al., 2011; Rajsekhar et al., 2015). Wisner et al. (1994) defined risk as a product of hazard and vulnerability. In the case of drought too, several studies have used the similar definition to identify drought risk pattern. Although multiple studies evaluated drought risk assessment, only few of them considered incorporating both hazard and vulnerability factors together (Rajsekhar et al., 2015) to investigate the socioeconomic ability of the region to cope with the drought event (Shahid and Behrawan, 2008).

Application of some of the drought studies based on socioeconomic information include, potential drought-related impact by considering environmental and socio-economic factors (Knutson et al., 1998); integration of stakeholder's information in drought vulnerability assessment (Fontaine and Steinemann 2009); System-based agricultural drought vulnerability assessment (Wilhelmi and Wilhite, 2002) and drought risk assessment framework that incorporates hazard and vulnerability (Shahid and Behrawan, 2008) and later applied by Bin et al., (2011), Kim et al., (2013), and Zhang et al., (2014) by improving upon the weighting scheme. With this background, we developed a framework for drought risk assessment and to identify the most vulnerable regions in Turkey. To achieve this objective, we used rainfall data (250 gauges with data between 1971 and 2010) obtained from State Meteorological Service (TSMS) to calculate Standardized Precipitation Index (SPI). Then drought hazard is calculated by assigning weights and ratings to probability distribution of SPI of a rain gauge station (Kim et al., 2015). Regional vulnerability to droughts is then identified by integrating various socio-economic indicators like population density, irrigated land area and access to municipal water.

\section{Study Area and Data}

Turkey is an intercontinental (Europe and Asia) country located between 26-45E and 36-42N longitudes and latitudes respectively. We collected homogeneously distributed precipitation data from 250 rain gauges located in 81 administrative provinces on Turkey mainland (Fig. 1). Monthly precipitation data were obtained from Turkish State Meteorological Service (TSMS), (http://www.mgm.gov.tr) between 1971 and 2010. The north of the Turkey can be regarded as rainfall intense regions in comparison to other regions especially in winter and spring seasons. During 
Nat. Hazards Earth Syst. Sci. Discuss., https://doi.org/10.5194/nhess-2018-129

Manuscript under review for journal Nat. Hazards Earth Syst. Sci.

Discussion started: 11 June 2018

(c) Author(s) 2018. CC BY 4.0 License.
Natural Hazards

and Earth System

Sciences

Discussions

(c) $($ i)

summer droughts are prolonged towards south and west side of country. Agricultural sector and urban populations are settled on these regions due to favorable geographical features and climatic conditions. Therefore, strong relationship can be found between droughts and socio-economic impacts in populated provinces.

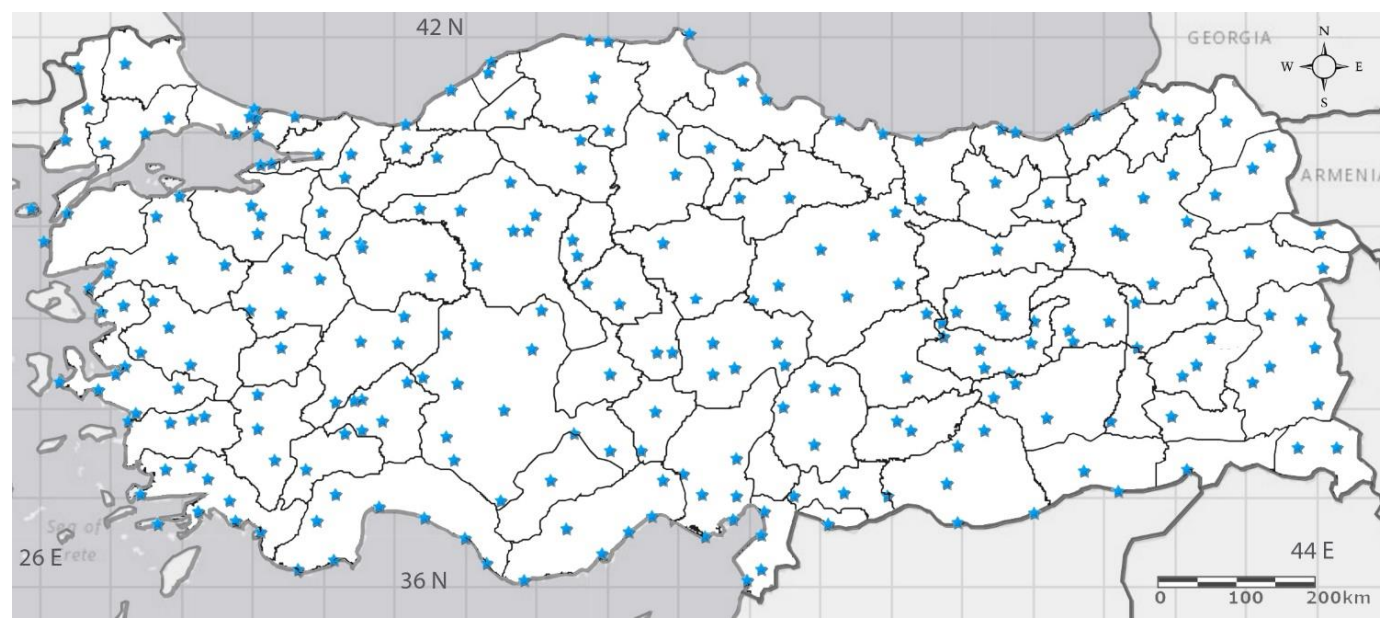

Fig. 1 Spatial map showing administrative provinces and selected rain gauges in Turkey (Number of administrative provinces: 81 ; Number of rain gauges: 250 )

The spatial pattern of annual rainfall is presented in Figure 2. It can be observed that annual rainfall increases towards the northeastern Black Sea coast of Turkey and the magnitude varies from $24 \mathrm{~cm}$ to $228 \mathrm{~cm}$. The driest regions are located in the middle and southeastern parts of Turkey, whereas the wettest pattern was observed in North-eastern parts with limited spatial extent.

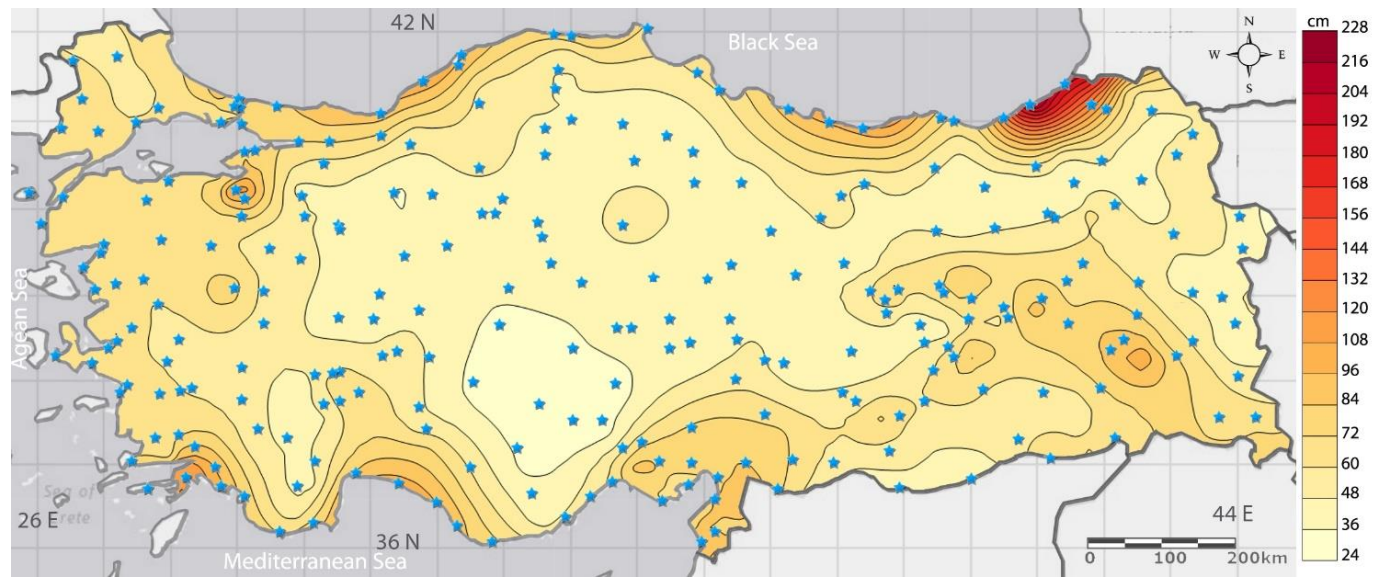

Fig. 2 Contour plot for annual rainfall from 250 homogeneously distributed gauges in Turkey

The socio-economic data, which includes population density; municipal water supply; agriculture and irrigated land information, were obtained from Turkish Statistical Institute (http://www.tuik.gov.tr). The percentages distribution of socio-economic data (based on total aggregation) for provinces are illustrated in Figure 3. It can be seen that population density is highly correlated with municipal water usage except few provinces (e.g., Muğla, Antalya, Hatay, and 
Nat. Hazards Earth Syst. Sci. Discuss., https://doi.org/10.5194/nhess-2018-129

Manuscript under review for journal Nat. Hazards Earth Syst. Sci.

Discussion started: 11 June 2018

(c) Author(s) 2018. CC BY 4.0 License.

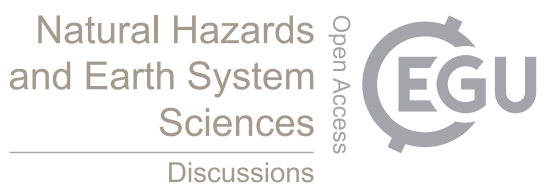

(c) $($ i)

Diyarbakır). On the other hand, total agricultural land and irrigated land are not strongly correlated for few provinces, for example, although total agricultural land of Ankara is classified in (4-6) \% interval, whereas irrigated land is scored within (0-2) \%. Similarly, total agricultural lands of several provinces are rather extensive; but irrigated lands are not equally extensive. So, severity of drought hazard in especially non-irrigated land areas could be more hazardous.

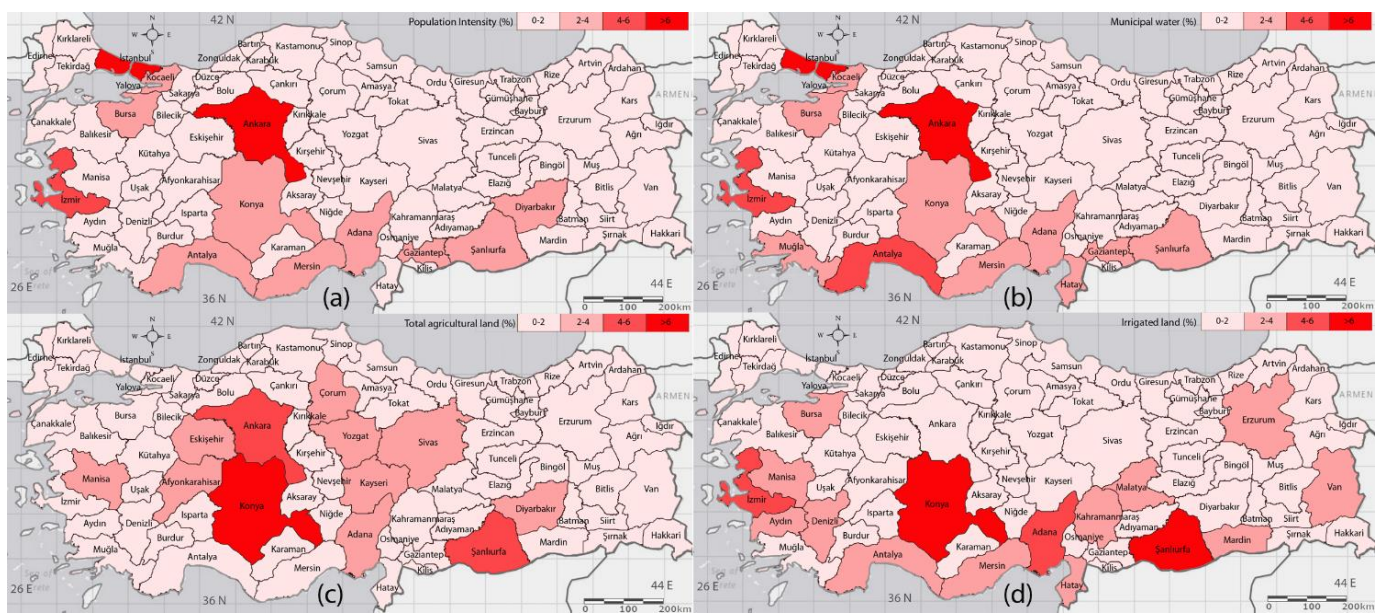

Fig. 3 Socio-economic data for provinces of Turkey: a) Population intensity (\%); b) Municipal water (\%); c) Total agricultural land (\%); and d) Irrigated land (\%)

\section{Methodology}

The SPI was used as a proxy to quantify drought. Risk assessment of an extreme event can be carried out using Hazard, Vulnerability and Risk (Rajsekhar et al., 2015; Singh, 2013). An overview of these methodologies is discussed here.

\subsection{Standardized Precipitation Index (SPI)}

The Standardized Precipitation Index (SPI, McKee et al., 1993; Guttman 1999) was used to quantify drought due to its simple procedures and standardization. SPI ensures that drought quantification at any location and on any time scale are consistent. The computational procedure for deriving SPI involves following steps: (a) first an appropriate probability density function (PDF) is fitted to the precipitation aggregated over the time scale of interest, and (b) each PDF is then transformed into a standardized normal probability distribution. The detailed mathematical procedure for calculation of SPI can be found in McKee et al., (1993), Guttman (1999), Mishra and Singh (2010) and Şen (2015). Considering that drought and its socio-economic impact evolve at longer temporal scale (window), we selected SPI-12 to quantify drought hazard, vulnerability and risk. The SPI based drought classification is presented in Table 1. 
Nat. Hazards Earth Syst. Sci. Discuss., https://doi.org/10.5194/nhess-2018-129

Manuscript under review for journal Nat. Hazards Earth Syst. Sci.

Discussion started: 11 June 2018

(c) Author(s) 2018. CC BY 4.0 License.

Table 1. Drought classifications based on SPI.

\begin{tabular}{ccc}
\hline Probability (\%) & SPI & Drought Category \\
\hline 2.30 & $\mathrm{SPI} \geq 2.00$ & extreme wet \\
4.40 & $2.00>\mathrm{SPI} \geq 1.50$ & very wet \\
9.20 & $1.50>\mathrm{SPI} \geq 1.00$ & moderate wet \\
68.20 & $1.00>\mathrm{SPI} \geq-1.00$ & normal \\
9.20 & $-1.00 \geq \mathrm{SPI}>-1.50$ & moderate drought \\
4.40 & $-1.50 \geq \mathrm{SPI}>-2.00$ & severe drought \\
2.30 & $-2.00 \geq \mathrm{SPI}$ & extreme drought \\
\hline \hline
\end{tabular}

\subsection{Drought Hazard Index (DHI)}

In general hazard quantifies the probability of occurrence of a potentially damaging phenomenon. Since hazard represents a probability, it ranges between 0 and 1 . Here, it is measured as the product of magnitude and the associated

5 frequency of occurrence of a drought event. Using a weighting system based on the cumulative distribution function (Fig. 4), Weight (W) and rating (R) scores are assigned based on the normal cumulative probability function to drought hazard assessment using severity and occurrence probability. Weight scores are determined by considering the SPI intervals, such that weight $=1$ for normal drought (ND), weight $=2$ for moderate drought (MD), weight $=3$ for severe drought (SD), and weight $=4$ for extreme drought $(\mathrm{ED})$. Weights for SPI $>0$ are equal to zero. Similarly, rating scores are assigned from 1 to 4 in increasing order dividing the interval of cumulative probabilities in each drought range.

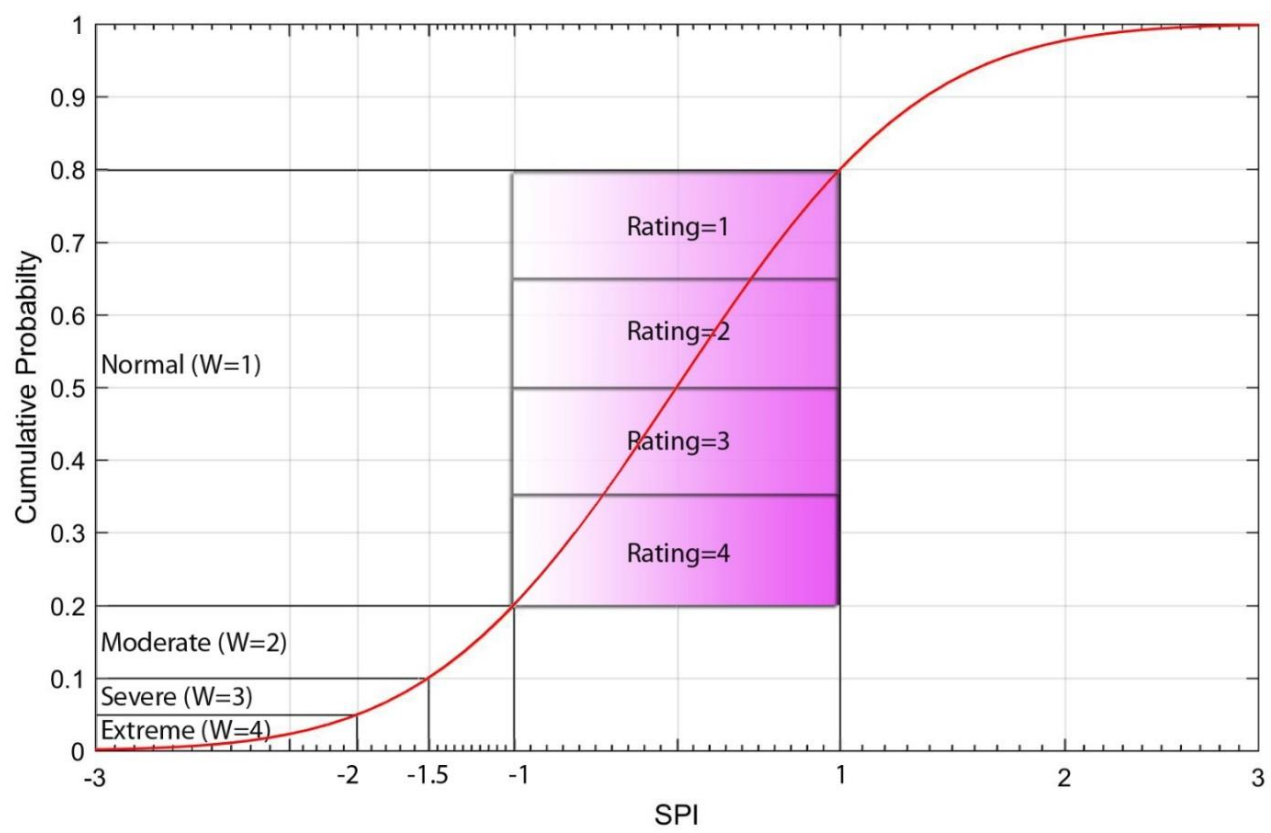

Fig. 4 Weight and rating scores based on normal cumulative probability distribution of SPI

The weight and rating scores are assigned based on the intervals which are illustrated Figure 4. Multiplication of weight and rating scores generates Drought Hazard Score (DHS). Then DHS is calculated for each SPI values between 1971 and 
Nat. Hazards Earth Syst. Sci. Discuss., https://doi.org/10.5194/nhess-2018-129

Manuscript under review for journal Nat. Hazards Earth Syst. Sci.

Discussion started: 11 June 2018

(c) Author(s) 2018. CC BY 4.0 License.

$$
(D H S)_{i}=\sum_{i=1}^{N_{S P I}} W_{i} x R_{i}
$$

where $\mathrm{N}_{\mathrm{SPI}}$ refers to number of SPI values for selected time interval. After obtaining DHSs for 250 gauges, drought hazard contour map (Fig. 6) is generated by using Kriging methodology. To obtain DHI for provinces, using contour map percentage area $\mathrm{A}(\%)$ and corresponding DHS are aggregated within province boundary by using Equation 2:

$$
(D H I)_{i}=\sum_{i=1}^{n} A(\%)_{i} x(D H S)_{i}
$$

This methodology is more appropriate way in comparison to Thiessen polygon methodology for DHI calculation for provinces. Boundaries of Thiessen polygons are generated sharp lines, however in this methodology, transitions of hazard region boundaries are smooth. Therefore, this approach can generate more realistic hazard scores in province scale.

\subsection{Drought Vulnerability Index (DVI)}

Vulnerability is a relative measure and it indicates the degree to which a system is susceptible to damage (harm) due to the occurrence of an event (Smit et al., 1999). Vulnerability is closely related to the socioeconomic conditions of a region and a potential indicator to measure maximum loss or harm during the event. Several studies conducted vulnerability assessment related to the effect of climate changes on water resources (Metzger et al., 2005), however they may not adequately reflect drought scenarios especially at the local level and may not be relevant across multiple sectors (Fontaine and Steinemann, 2009). Therefore, the selection of vulnerability indicators varies between sectors and their selection should be directly relevant to the local study context and the particular hazard.

Four socio-economic indicators are selected in this study, which includes, Irrigated Land (IL), Total Agricultural Land (TAL), Population Density (PD) and Municipal Water (MW) for calculating Drought Vulnerability Index (DVI) based on equation 3:

$$
D V I=\frac{I L_{n}+T A L_{n}+P D_{n}+M W_{n}}{4}
$$

Where $\mathrm{IL}_{\mathrm{n}}, \mathrm{TAL}_{\mathrm{n}}, \mathrm{PD}_{\mathrm{n}}$, and $\mathrm{MW}_{\mathrm{n}}$ are normalized values assigned to irrigated land, total agricultural land, population density, and municipal water, respectively. Each indicator is normalized within own range and common distribution interval is adjusted for all indicators to overcome the different unit effects. Then, the DVI is re-scaled into four classes: Low vulnerability $(0<$ DVI $<0.25)$; Moderate $(0.25<$ DVI $<0.50)$; High $(0.5<$ DVI $<0.75)$ and Very high $(0.75<$ DVI $<1.0)$.

\subsection{Drought Risk Index (DRI)}

Drought risk assessment is investigated by incorporating the hazard and vulnerability assessments. Typically, the Drought Risk Index (DRI) is calculated as multiplication between DHI and DVI. There will be no risk when either of DVI or DHI is 0, however, higher value of either DVI or DHI will result in increased risk from the drought event. Therefore, to quantify drought risk both hazard and vulnerability information is essential. The quantitative assessments of drought risk are vital for coping with drought hazard consequences; therefore, Drought Risk Index is calculated by using a conceptual model presented in Figure 5 using Drought Hazard Index (DHI) and drought Vulnerability Index (DVI). 
Nat. Hazards Earth Syst. Sci. Discuss., https://doi.org/10.5194/nhess-2018-129

Manuscript under review for journal Nat. Hazards Earth Syst. Sci.

Discussion started: 11 June 2018

(c) Author(s) 2018. CC BY 4.0 License.
Natural Hazards

and Earth System

Sciences

Discussions

(c) (i)

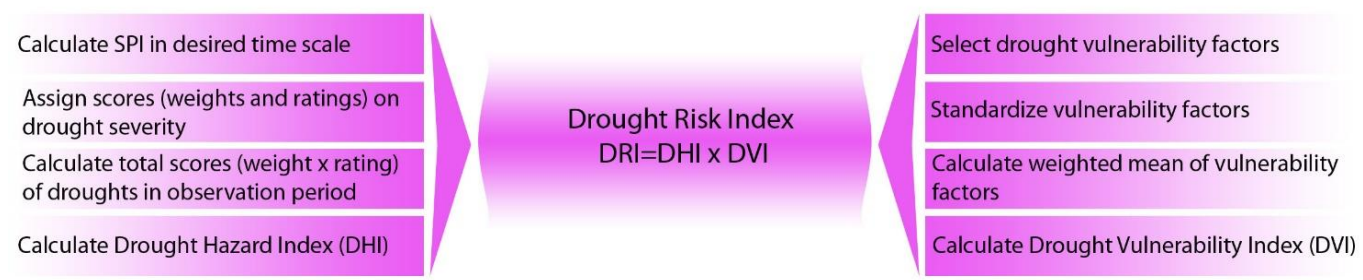

Fig. 5 Conceptual model procedure of drought risk assessment

\section{Results and discussion}

\subsection{Drought hazard assessment}

5 After obtaining DHSs for 250 gauges, drought hazard contour map is generated by using Kriging methodology as seen in Figure 6. Cumulative sum of DHS values between 1971 and 2010 can be directly related to drought hazard. Accordingly, Figure 6 proves consistency with higher drought scores over southern and western parts of Turkey. Because, magnitude of precipitation is lower in southern and western parts of Turkey.

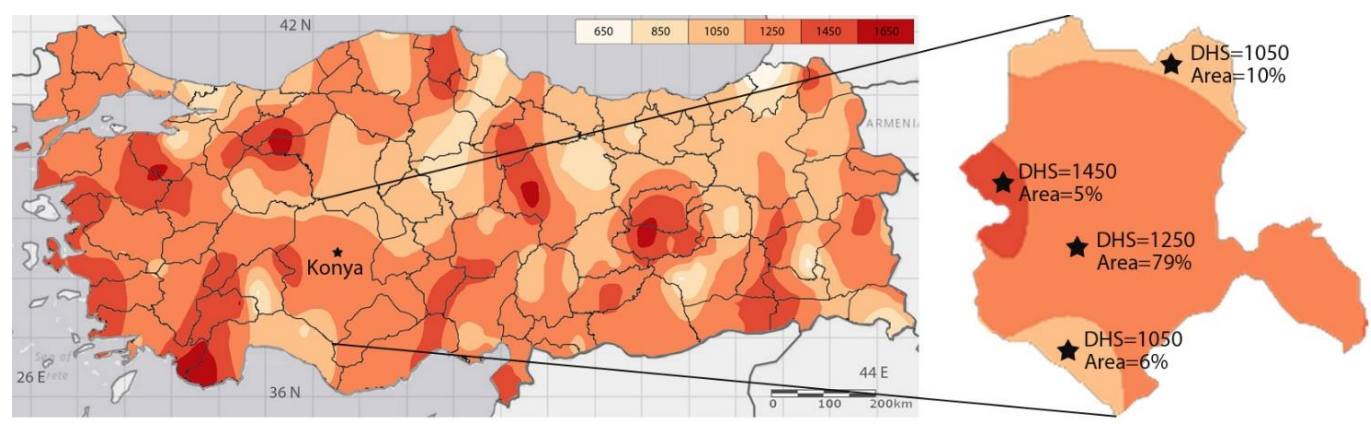

Fig. 6 Drought hazard assessment contour maps and sample illustration DHS and corresponding areas of Konya for DHI calculation

The cumulative distributions of DHS for rain gauges are fitted by normal CDF as seen in Figure 7. The fitted normal CDF is validated by Kolmogorov-Smirnov test for $95 \%$ confidence interval. It is expected that; SPI and DHS

15 distributions should be similar probability distributions. Therefore, this coherence of normal probability distribution makes DHS calculation well directed. 
Nat. Hazards Earth Syst. Sci. Discuss., https://doi.org/10.5194/nhess-2018-129

Manuscript under review for journal Nat. Hazards Earth Syst. Sci.

Discussion started: 11 June 2018

(c) Author(s) 2018. CC BY 4.0 License.
Natural Hazards

and Earth System

Sciences

Discussions

(c) (i)

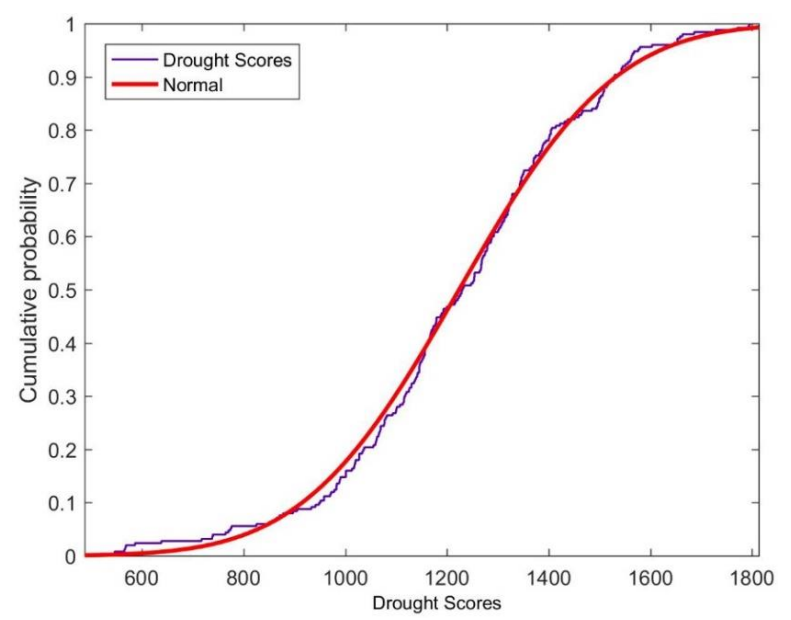

Fig. 7 The CDF of total drought scores in average of 250 stations between 1971 and 2010

To obtain province scale DHI, contour map percentage area A $(\%)$ and corresponding DHS are aggregated within province boundary by using Equation 2. In Figure 6, DHS and corresponding area percentage are presented for Konya which is the largest province of Turkey to illustrate the DHI calculation procedures.

First drought hazard scores (DHS) and drought severity percentages are calculated. Then, DHI is calculated as 1229 $(1229=1250 \times 0.79+1450 \times 0.05+1050 \times 0.16)$ by using Equation 2 for Konya. The similar calculation procedure is applied for 81 provinces in Turkey. Then, DHI scores are normalized through re-scaling between 0 and 1 . Provinces of Turkey are classified based on the DHI into four classes such as "Low" between 0 and 0.25 , "Moderate" between 0.25 and 0.50 , "High" between 0.5 and 0.75 , "Very High" between 0.75 and 1.0. After obtaining four drought hazard classes, drought hazard map is generated as shown in Figure 8. The DHI map shows more severity on south and west provinces of Turkey. Because south and west part of the Turkey's altitudes are lower with respect to the east and north. This feature makes these provinces warmer due to the sea effects as well.

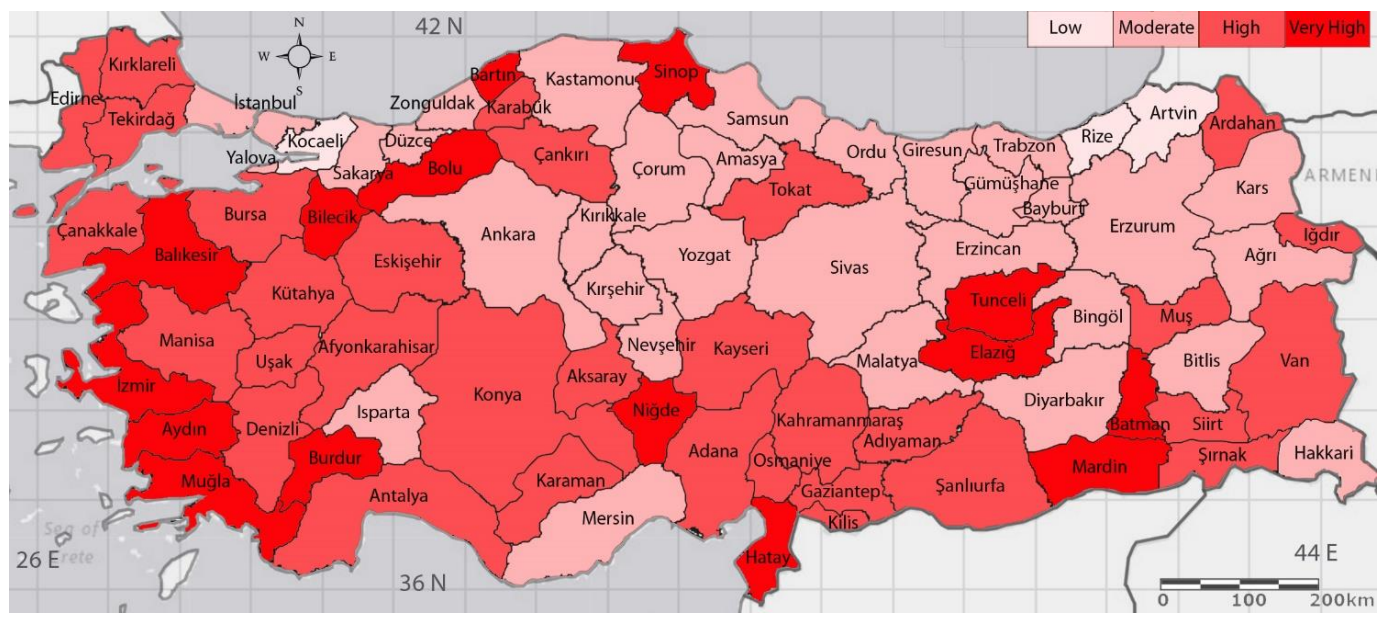

Fig. 8 Drought hazard map for Turkey based on DHI

\subsection{Drought Vulnerability Assessment}


Nat. Hazards Earth Syst. Sci. Discuss., https://doi.org/10.5194/nhess-2018-129

Manuscript under review for journal Nat. Hazards Earth Syst. Sci.

Discussion started: 11 June 2018

(c) Author(s) 2018. CC BY 4.0 License.

Generally, vulnerability is known as an indicator of sensibility or resilience to cope with the consequences of natural disasters (Wilhelmi and Wilhite, 2002). Several studies investigated the link between climate change impacts on water resources and drought vulnerability (Eakin and Conley, 2002; Metzger et al., 2005; Brooks et al., 2005; Kim et al., 2015), however, the objective assessment of vulnerability often neglects socio-economic variables. Therefore, we incorporated several socio-economic local variables to assess drought vulnerability to fill these kinds of regional assessment gap.

Prolonged drought event has a direct impact on socio-economic sectors, for example, the rate of evapotranspiration increases during drought period leading to depletion in soil moisture which is directly linked to the agricultural activity and food productions. Similarly, the reductions in streamflow and reservoir storage cause agricultural and municipal water supply deficits. Thus, drought is directly associated with municipal and agricultural water shortages which severely affects irrigated agricultural areas, and population. In this paper, depending on the availability of reliable socio-economic data, four indicators are selected, such as Irrigated Land (IL), Total Agricultural Land (TAL), Population Density (PD) and Municipal Water (MW). First, the drought vulnerability is calculated by using four socioeconomic indicators parameters into Equation 3. Then, vulnerability map based on DVI is presented as seen in Figure 9. It was observed that Konya and Şanlıurfa witnessed very high vulnerability because of their extensive agricultural lands, whereas, Istanbul is designated as very high vulnerability because of its population density. Similarly, Adana, Ankara and Izmir are identified as high vulnerability because of their dense population and large agricultural land. Likewise, many interpretations can be extracted from this vulnerability map to understand existing vulnerability circumstances of each province in Turkey. The common feature for moderate vulnerability regions that consist of 15 provinces can be attributed to agriculture and population density. In these 15 provinces, the ratio of Irrigated Land (IL), Total Agricultural Land (TAL), Population Density (PD) and Municipal Water (MW) are calculated as 36\%,26\%,27\%, and 29\%, respectively. Furthermore, it can be interpreted that northern Turkey's vulnerability is low due to the relatively lower population and agricultural land. Most of the provinces in northern and eastern side of Turkey are located at higher altitudes with mountainous areas and it may be possible to say that lower vulnerability pattern may be correlated with physical elevation of Turkey.

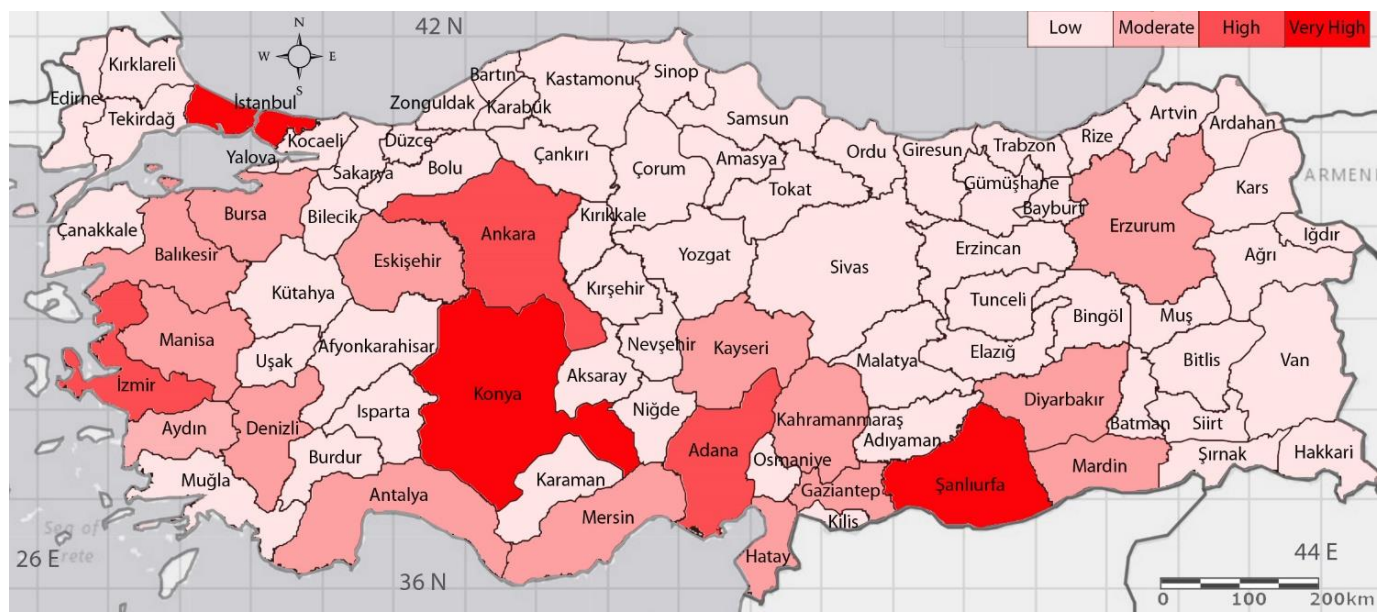

Fig. 9 Drought vulnerability map for Turkey based on DVI

\subsection{Drought Risk Index Assessment}


Nat. Hazards Earth Syst. Sci. Discuss., https://doi.org/10.5194/nhess-2018-129

Manuscript under review for journal Nat. Hazards Earth Syst. Sci.

Discussion started: 11 June 2018

(c) Author(s) 2018. CC BY 4.0 License.

In this paper, the drought risk index (DRI) is generated based on meteorological and socio-economic information by multiplying drought hazard index (DHI) and drought vulnerability index (DVI). The drought risk map is generated based on DRI as presented in Figure 10. Each province is categorized into four groups similar to DHI and DVI class intervals.

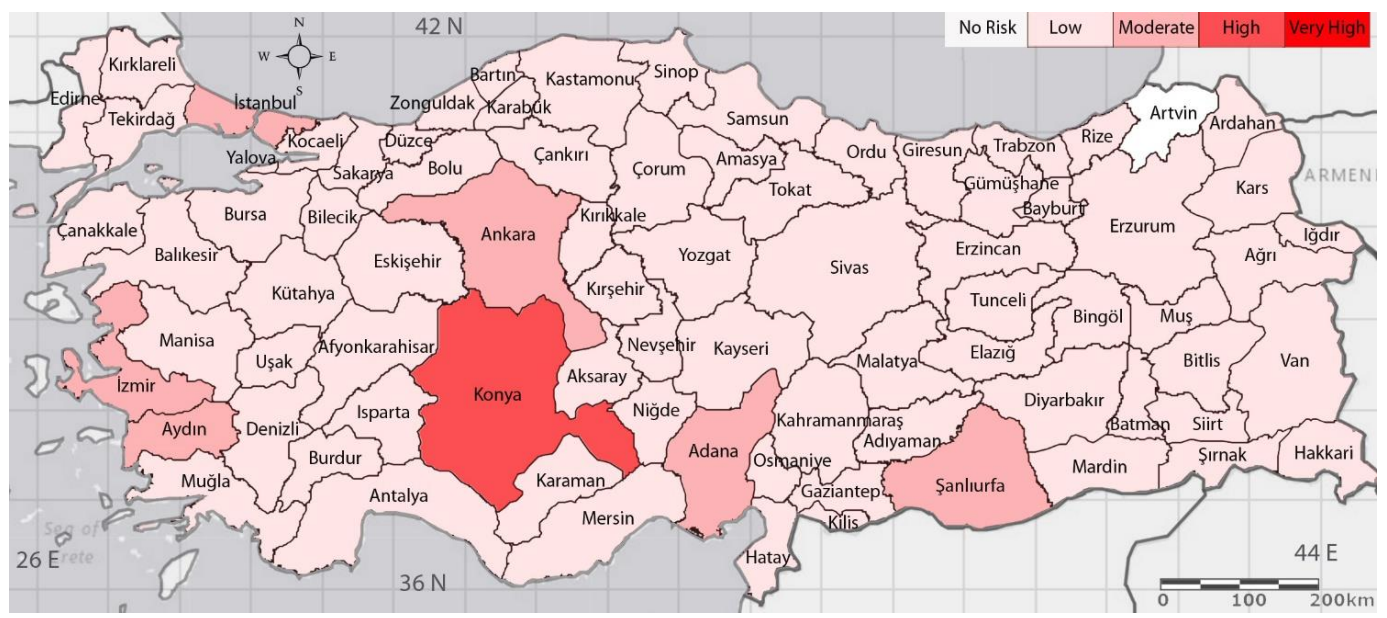

Fig. 10 Drought risk map for Turkey based on DRI

If one of DVI or DHI is equal to "0", the DRI score becomes " 0 ", which means there is no drought risk, for example Artvin province as seen in Figure 10. Similarly, if one of DVI or DHI is higher, then the DRI becomes higher. In other words, DVI and DHI make important contributions on DRI assessment. This drought risk assessment method can able to identify as well as compare drought risk among provinces to reduce and mitigate the adverse results of drought hazard. The generated maps for drought hazard, vulnerability, and risk for 81 provinces of Turkey will help to identify spatial distribution of drought risk indicators. Based on the DHI map (Fig. 8), Sinop, Bartın, Bolu, Bilecik, Balıkesir, Izmir, Aydın, Muğla, Burdur, Niğde, Hatay, Mardin, Batman, Elazığ and Tunceli are classified in the highest level of drought hazard. Whereas, depending on the DVI maps in Figure 9, three major provinces (Istanbul, Konya and Şanlıurfa) have very high degree of vulnerability. Hence, considering both the DHI and the DVI, the DRI map (Fig. 10) indicates Konya province poses a highest drought risk in Turkey. Also, Istanbul, Ankara, Izmir, Adana, Şanlıurfa and Aydın have moderate drought risk based on DRI scores. The results of DHI, DVI and DRI are summarized in Table 2 to identify drought risk for provinces of Turkey. 
Nat. Hazards Earth Syst. Sci. Discuss., https://doi.org/10.5194/nhess-2018-129

Manuscript under review for journal Nat. Hazards Earth Syst. Sci.

Discussion started: 11 June 2018

(c) Author(s) 2018. CC BY 4.0 License.

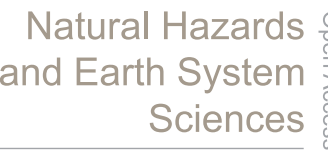

Discussions

Table 2. DHI, DVI and DRI scores for 81 provinces in Turkey.

\begin{tabular}{|c|c|c|c|c|c|c|c|}
\hline \multirow[b]{2}{*}{ No } & \multirow[b]{2}{*}{ Province } & \multicolumn{2}{|r|}{ DHI } & \multicolumn{2}{|r|}{ DVI } & \multicolumn{2}{|r|}{ DRI } \\
\hline & & Score & Class & Score & Class & Score & Class \\
\hline 1 & Adana & 0.59 & HIGH & 0.52 & HIGH & 0.30 & MODERATE \\
\hline 2 & Adiyaman & 0.73 & HIGH & 0.14 & LOW & 0.10 & LOW \\
\hline 3 & Afyonkarahisar & 0.67 & HIGH & 0.21 & LOW & 0.14 & LOW \\
\hline 4 & Ağr1 & 0.46 & MODERATE & 0.20 & LOW & 0.09 & LOW \\
\hline 5 & Amasya & 0.34 & MODERATE & 0.13 & LOW & 0.05 & LOW \\
\hline 6 & Ankara & 0.46 & MODERATE & 0.67 & HIGH & 0.31 & MODERATE \\
\hline 7 & Antalya & 0.61 & HIGH & 0.37 & MODERATE & 0.23 & LOW \\
\hline 8 & Artvin & 0.00 & NO & 0.04 & LOW & 0.00 & NO \\
\hline 9 & Aydın & 0.82 & VERY HIGH & 0.33 & MODERATE & 0.27 & MODERATE \\
\hline 10 & Balıkesir & 0.87 & VERY HIGH & 0.25 & MODERATE & 0.22 & LOW \\
\hline 11 & Bilecik & 0.75 & VERY HIGH & 0.04 & LOW & 0.03 & LOW \\
\hline 12 & Bingöl & 0.32 & MODERATE & 0.06 & LOW & 0.02 & LOW \\
\hline 13 & Bitlis & 0.48 & MODERATE & 0.08 & LOW & 0.04 & LOW \\
\hline 14 & Bolu & 0.82 & VERY HIGH & 0.05 & LOW & 0.04 & LOW \\
\hline 15 & Burdur & 0.87 & VERY HIGH & 0.10 & LOW & 0.08 & LOW \\
\hline 16 & Bursa & 0.63 & HIGH & 0.32 & MODERATE & 0.20 & LOW \\
\hline 17 & Çanakkale & 0.72 & HIGH & 0.17 & LOW & 0.12 & LOW \\
\hline 18 & Çankırı & 0.63 & HIGH & 0.08 & LOW & 0.05 & LOW \\
\hline 19 & Çorum & 0.34 & MODERATE & 0.20 & LOW & 0.07 & LOW \\
\hline 20 & Denizli & 0.73 & HIGH & 0.30 & MODERATE & 0.22 & LOW \\
\hline 21 & Diyarbakır & 0.39 & MODERATE & 0.29 & MODERATE & 0.11 & LOW \\
\hline 22 & Edirne & 0.65 & HIGH & 0.14 & LOW & 0.09 & LOW \\
\hline 23 & Elazığg & 0.95 & VERY HIGH & 0.14 & LOW & 0.14 & LOW \\
\hline 24 & Erzincan & 0.42 & MODERATE & 0.10 & LOW & 0.04 & LOW \\
\hline 25 & Erzurum & 0.37 & MODERATE & 0.31 & MODERATE & 0.11 & LOW \\
\hline 26 & Eskişehir & 0.57 & HIGH & 0.28 & MODERATE & 0.16 & LOW \\
\hline 27 & Gaziantep & 0.62 & HIGH & 0.28 & MODERATE & 0.18 & LOW \\
\hline 28 & Giresun & 0.26 & MODERATE & 0.07 & LOW & 0.02 & LOW \\
\hline 29 & Gümüşhane & 0.31 & MODERATE & 0.04 & LOW & 0.01 & LOW \\
\hline 30 & Hakkari & 0.27 & MODERATE & 0.05 & LOW & 0.01 & LOW \\
\hline 31 & Hatay & 0.82 & VERY HIGH & 0.30 & MODERATE & 0.25 & LOW \\
\hline 32 & Isparta & 0.47 & MODERATE & 0.12 & LOW & 0.06 & LOW \\
\hline 33 & Mersin & 0.39 & MODERATE & 0.35 & MODERATE & 0.13 & LOW \\
\hline 34 & İstanbul & 0.29 & MODERATE & 0.90 & VERY HIGH & 0.26 & MODERATE \\
\hline 35 & İzmir & 0.91 & VERY HIGH & 0.54 & HIGH & 0.49 & MODERATE \\
\hline 36 & Kars & 0.40 & MODERATE & 0.08 & LOW & 0.03 & LOW \\
\hline 37 & Kastamonu & 0.43 & MODERATE & 0.08 & LOW & 0.04 & LOW \\
\hline 38 & Kayseri & 0.66 & HIGH & 0.27 & MODERATE & 0.18 & LOW \\
\hline 39 & Kırklareli & 0.62 & HIGH & 0.09 & LOW & 0.05 & LOW \\
\hline 40 & Kırşehir & 0.29 & MODERATE & 0.13 & LOW & 0.04 & LOW \\
\hline 41 & Kocaeli & 0.14 & LOW & 0.15 & LOW & 0.02 & LOW \\
\hline 42 & Konya & 0.62 & HIGH & 1.00 & VERY HIGH & 0.62 & HIGH \\
\hline 43 & Kütahya & 0.72 & HIGH & 0.12 & LOW & 0.09 & LOW \\
\hline 44 & Malatya & 0.45 & MODERATE & 0.23 & LOW & 0.10 & LOW \\
\hline 45 & Manisa & 0.66 & HIGH & 0.36 & MODERATE & 0.24 & LOW \\
\hline 46 & Kahramanmaraş & 0.50 & HIGH & 0.36 & MODERATE & 0.18 & LOW \\
\hline 47 & Mardin & 0.76 & VERY HIGH & 0.28 & MODERATE & 0.21 & LOW \\
\hline 48 & Muğla & 0.88 & VERY HIGH & 0.19 & LOW & 0.17 & LOW \\
\hline 49 & Muş & 0.58 & HIGH & 0.13 & LOW & 0.07 & LOW \\
\hline 50 & Nevşehir & 0.44 & MODERATE & 0.14 & LOW & 0.06 & LOW \\
\hline 51 & Niğde & 0.84 & VERY HIGH & 0.15 & LOW & 0.13 & LOW \\
\hline 52 & Ordu & 0.31 & MODERATE & 0.11 & LOW & 0.03 & LOW \\
\hline
\end{tabular}


Nat. Hazards Earth Syst. Sci. Discuss., https://doi.org/10.5194/nhess-2018-129

Manuscript under review for journal Nat. Hazards Earth Syst. Sci.

Discussion started: 11 June 2018

(c) Author(s) 2018. CC BY 4.0 License.
Natural Hazards

and Earth System

Sciences

Discussions

Table 2. Continue.

\begin{tabular}{|c|c|c|c|c|c|c|c|}
\hline 53 & Rize & 0.18 & LOW & 0.03 & LOW & 0.01 & LOW \\
\hline 54 & Sakarya & 0.47 & MODERATE & 0.15 & LOW & 0.07 & LOW \\
\hline 55 & Samsun & 0.31 & MODERATE & 0.24 & LOW & 0.07 & LOW \\
\hline 56 & Siirt & 0.63 & HIGH & 0.06 & LOW & 0.04 & LOW \\
\hline 57 & Sinop & 0.84 & VERY HIGH & 0.05 & LOW & 0.04 & LOW \\
\hline 58 & Sivas & 0.50 & MODERATE & 0.26 & MODERATE & 0.13 & LOW \\
\hline 59 & Tekirdağ & 0.64 & HIGH & 0.14 & LOW & 0.09 & LOW \\
\hline 60 & Tokat & 0.67 & HIGH & 0.16 & LOW & 0.11 & LOW \\
\hline 61 & Trabzon & 0.31 & MODERATE & 0.08 & LOW & 0.02 & LOW \\
\hline 62 & Tunceli & 0.89 & VERY HIGH & 0.04 & LOW & 0.03 & LOW \\
\hline 63 & Şanlıurfa & 0.61 & HIGH & 0.75 & VERY HIGH & 0.46 & MODERATE \\
\hline 64 & Uşak & 0.65 & HIGH & 0.07 & LOW & 0.05 & LOW \\
\hline 65 & Van & 0.63 & HIGH & 0.26 & MODERATE & 0.16 & LOW \\
\hline 66 & Yozgat & 0.26 & MODERATE & 0.20 & LOW & 0.05 & LOW \\
\hline 67 & Zonguldak & 0.42 & MODERATE & 0.05 & LOW & 0.02 & LOW \\
\hline 68 & Aksaray & 0.53 & HIGH & 0.16 & LOW & 0.08 & LOW \\
\hline 69 & Bayburt & 0.31 & MODERATE & 0.05 & LOW & 0.02 & LOW \\
\hline 70 & Karaman & 0.65 & HIGH & 0.14 & LOW & 0.09 & LOW \\
\hline 71 & Kırıkkale & 0.31 & MODERATE & 0.09 & LOW & 0.03 & LOW \\
\hline 72 & Batman & 0.77 & VERY HIGH & 0.08 & LOW & 0.06 & LOW \\
\hline 73 & Şırnak & 0.66 & HIGH & 0.07 & LOW & 0.05 & LOW \\
\hline 74 & Bartın & 1.00 & VERY HIGH & 0.02 & LOW & 0.02 & LOW \\
\hline 75 & Ardahan & 0.62 & HIGH & 0.02 & LOW & 0.01 & LOW \\
\hline 76 & Iğdır & 0.65 & HIGH & 0.08 & LOW & 0.05 & LOW \\
\hline 77 & Yalova & 0.40 & MODERATE & 0.03 & LOW & 0.01 & LOW \\
\hline 78 & Karabük & 0.65 & HIGH & 0.03 & LOW & 0.02 & LOW \\
\hline 79 & Kilis & 0.60 & HIGH & 0.04 & LOW & 0.02 & LOW \\
\hline 80 & Osmaniye & 0.65 & HIGH & 0.11 & LOW & 0.07 & LOW \\
\hline 81 & Düzce & 0.44 & MODERATE & 0.05 & LOW & 0.02 & LOW \\
\hline
\end{tabular}

Among 81 provinces of Turkey (with respect to Table 2), 73 provinces are exposed to the low drought risk $(0<$ DRI $<$ $0.25), 6$ provinces to the moderate drought risk $(0.25<\mathrm{DRI}<0.50), 1$ province (Konya) to the high drought risk $(0.50<$ DRI < 0.75), and only 1 province (Artvin) to the no drought risk (DRI $=0.00)$. The district of Konya has extensive agricultural and irrigated land which leads it to the high drought vulnerability and risk. Whereas, Arvin has relatively

5 zero DHI which results no drought risk, which may be due to its highest amount of annual rainfall among the provinces. Among the moderate risk scored provinces, Istanbul can be explained by highest population density. However, other provinces in moderate score level (Ankara, Adana, İzmir, Aydın, and Şanlıurfa) can be explained by both agricultural land and population density with respect to low scored provinces.

To the best of our knowledge, previous studies did not assess drought risk based on DVI and DHI for provinces of

10 Turkey. Therefore, this approach can provide meaningful information for improving Turkey's drought management. High risk provinces can mitigate drought risk through the innovative water resources management. Also, it can be recommended that policy makers should develop appropriate measures to protect existing water supplies in risky provinces.

\section{Conclusion}

15 In this paper, spatial drought risk pattern is quantified by incorporating hazard and vulnerability for provinces located in Turkey. The drought hazard index is identified by using SPI weight and rating scores between 1971 and 2010. The 
Nat. Hazards Earth Syst. Sci. Discuss., https://doi.org/10.5194/nhess-2018-129

Manuscript under review for journal Nat. Hazards Earth Syst. Sci.

Discussion started: 11 June 2018

(c) Author(s) 2018. CC BY 4.0 License. vulnerability, and risk maps are generated based on DHI, DVI and DRI for investigating spatial variability of droughts. It was observed that 73 cities are exposed to the low drought risk $(0<\mathrm{DRI}<0.25), 6$ cities to the moderate drought risk $(0.25<\mathrm{DRI}<0.50), 1$ city (Konya) to the high drought risk $(0.50<\mathrm{DRI}<0.75)$, and finally only 1 city (Artvin) to the no drought risk (DRI=0.00). Furthermore, the conceptual drought risk model which depends on actual socio-economic variables can help to minimize drought impacts in Turkey. Overall this information can be used to identify provinces which are most vulnerable to drought as well as an relative assessment between provinces. Additional (i.e., current or future) socio-economic indicators can be further included to generate drought risk maps for scenario analysis as well as to develop strategies to minimize socio-economic impacts.

\section{Acknowledgments}

This study is supported by The Scientific and Technological Research Council of Turkey (TUBITAK) with grand number 1059B141501044. The corresponding author would like to express his appreciation to TUBITAK for its research support at Clemson University. Also, the authors wish to thank Turkish State Meteorological Service (TSMS) for the supply of long-term monthly mean climatic variables.

\section{References}

Brooks, N., Adger, W., Kelly, P., (2005). The determinants of vulnerability and adaptive capacity at the national level and the implications for adaptation. Glob. Environ. Change 15, 151-163. http://doi.org/10.1016/j.gloenvcha.2004.12.006

Dai, A. (2011). Drought under global warming: A review. Wiley Interdisciplinary Reviews: Climate Change, 2(1), 4565. http://doi.org/10.1002/wcc. 81

Dai, A. (2013). Increasing drought under global warming in observations and models. Nature Climate Change, 3(1), 5258. http://doi.org/10.1038/nclimate1633

Diffenbaugh, N. S., \& Giorgi, F. (2012). Climate change hotspots in the CMIP5 global climate model ensemble. Climatic change, 114(3-4), 813-822. http://doi.org/10.1007/s10584-012-0570-X

Dogan, S., Berktay, A., \& Singh, V. P. (2012). Comparison of multi-monthly rainfall-based drought severity indices, with application to semi-arid Konya closed basin, Turkey. Journal of Hydrology, 470-471, 255-268. http://doi.org/10.1016/j.jhydrol.2012.09.003

Eakin, H., Conley, J., (2002). Climate variability and the vulnerability of ranching in southeastern Arizona: a pilot study. Clim. Res. 21, 271-282.

Gampe, D., Ludwig, R., Qahman, K., \& Afifi, S. (2016). Applying the Triangle Method for the parameterization of irrigated areas as input for spatially distributed hydrological modeling - Assessing future drought risk in the Gaza Strip (Palestine). Science of the Total Environment, 543, 877-888. http://doi.org/10.1016/j.scitotenv.2015.07.098

Guttman, N. B. (1999). Accepting the Standardized Precipitation Index: a Calculation Algorithm1. JAWRA Journal of the American Water Resources Association, 35(2), 311-322. http://doi.org/10.1111/j.1752-1688.1999.tb03592.x

Jia, H., \& Wang, D. P. J. (2016). Risk mapping of integrated natural disasters in China. Natural Hazards, 80(3), 20232035. http://doi.org/10.1007/s11069-015-2057-3 
Nat. Hazards Earth Syst. Sci. Discuss., https://doi.org/10.5194/nhess-2018-129

Manuscript under review for journal Nat. Hazards Earth Syst. Sci.

Discussion started: 11 June 2018

(c) Author(s) 2018. CC BY 4.0 License.

Kahraman, C., \& Kaya, İ. (2009). Fuzzy process accuracy index to evaluate risk assessment of drought effects in Turkey. Human and Ecological Risk Assessment, 15(4), 789-810. http://doi.org/10.1080/10807030903051242

Kim, H., Park, J., Yoo, J., \& Kim, T. (2015). Assessment of drought hazard, vulnerability, and risk: A case study for administrative districts in South Korea. Journal of Hydro-Environment Research, 9(1), $28-35$. http://doi.org/10.1016/j.jher.2013.07.003

Lin, M.L., Chu, C.M., Tsai, B.W., (2011). Drought risk assessment in western Inner-Mongolia. Int. J. Environ. Res. 5 (1), $139 \mathrm{e} 148$.

McKee, T.B., Doesken, N.J., Kleist, J., (1993). The relationship of drought frequency and duration time scales. In: Eighth Conference on Applied Climatology. American Meteorological Society, Anaheim, California.

Metzger, M.J., Leemans, R., Schröter, D., (2005). A multidisciplinary multiscale framework for assessing vulnerabilities to global change. Int. J. Appl. Earth Obs. 7, 253-267. http://doi.org/10.1016/j.jag.2005.06.011

Mishra, A. K., \& Singh, V. P. (2010). A review of drought concepts. Journal of Hydrology, 391(1-2), $202-216$. http://doi.org/10.1016/j.jhydrol.2010.07.012

Pei, W., Fu, Q., \& Li, D. L. T. (2016). Assessing agricultural drought vulnerability in the Sanjiang Plain based on an improved projection pursuit model. Natural Hazards, 82(1), 683-701. http://doi.org/10.1007/s11069-016-2213-4

Rahman, R., \& Lateh, H. (2016). Meteorological drought in Bangladesh: assessing, analyzing and hazard mapping using SPI, GIS and monthly rainfall data. Environmental Earth Sciences, 75(12), 1-20. http://doi.org/10.1007/s12665$\underline{016-5829-5}$

Rajsekhar, D., V. P. Singh, and A. K. Mishra (2015), Integrated drought causality, hazard, and vulnerability assessment for future socioeconomic scenarios: An information theory perspective. J. Geophys. Res. Atmos., 120, 6346-6378. http://doi.org/10.1002/2014JD022670

Shahid, S., Behrawan, H., (2008). Drought risk assessment in the western part of Bangladesh. Nat. Hazards, 46, 391-413. http://doi.org/10.1007/s11069-007-9191-5

Sönmez, F. K., Kömüşcü, A. Ü., Erkan, A., \& Turgu, E. (2005). An analysis of spatial and temporal dimension of drought vulnerability in Turkey using the standardized precipitation index. Natural Hazards, 35(2), 243-264. http://doi.org/10.1007/s11069-004-5704-7

Şen, B., Topcu, S., Türkeș, M., Sen, B., \& Warner, J. F. (2012). Projecting climate change, drought conditions and crop productivity in Turkey. Climate Research, 52, 175-191. https://doi.org/10.3354/cr01074

Şen, Z. (2015). Applied Drought Modeling, Prediction, and Mitigation, 1st Edition, Elsevier, Amsterdam, 484p.

Trenberth, K. E. (2011). Changes in precipitation with climate change. Climate Research, 47(1-2), 123-138. https://doi.org/10.3354/cr00953

Tosunoglu, F., \& Can, I. (2016). Application of copulas for regional bivariate frequency analysis of meteorological droughts in Turkey. Natural Hazards, 82(3), 1457-1477. http://doi.org/10.1007/s11069-016-2253-9

Türkeş, M., \& Erlat, E. (2003). Precipitation changes and variability in Turkey linked to the North Atlantic oscillation during the period 1930-2000. International Journal of Climatology, 23(14), 1771-1796. http://doi.org/10.1002/joc. 962

UNDP, United Nation Development Program, (2004). Reducing Disaster Risk: a Challenge for Development. John S. Swift Co, New York. 
Nat. Hazards Earth Syst. Sci. Discuss., https://doi.org/10.5194/nhess-2018-129

Manuscript under review for journal Nat. Hazards Earth Syst. Sci.

Discussion started: 11 June 2018

(c) Author(s) 2018. CC BY 4.0 License.

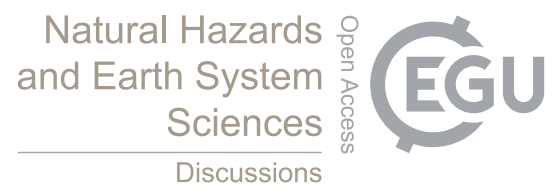

(c) (i)

Venkataraman, K., Tummuri, S., Medina, A., \& Perry, J. (2016). 21st century drought outlook for major climate divisions of Texas based on CMIP5 multimodel ensemble: Implications for water resource management. Journal of Hydrology, 534, 300-316. http://doi.org/10.1016/j.jhydrol.2016.01.001

Verdon-Kidd, D.C., Kiem, A.S., (2010). Quantifying drought risk in a nonstationary climate. J. Hydrometeorol. 11, 1019-1031. http://doi.org/10.1175/2010JHM1215.1

Wilhelmi, O.V., Wilhite, D.A., (2002). Assessing vulnerability to agricultural drought: a Nebraska case study. Nat. Hazards 25, 37-58. http://doi.org/10.1023/A:1013388814894

Wisner, B., Blaikie, P., Cannon, T., Davis, I., (1994). At risk: natural hazards, peoples vulnerability and disasters. London, UK.

10 Worldbank, (2015). Mind, Society, and Behavior. Washington D.C., USA

Zhang, K., Kimball, J. S., Nemani, R. R., and Running, S. W., (2010): A continuous satellite-derived global record of land surface evapotranspiration from 1983 to 2006, Water Resour. Res., 46, W09522, http://doi.org/10.1029/2009wr008800 